\title{
FEATURES OF THE DIGITAL ECONOMY DEVELOPMENT IN THE EAEU COUNTRIES
}

\author{
Ekaterina A. Sidorova \\ International Academy of Business and New Technologies, Yaroslavl, Russian Federation
}

\begin{abstract}
The most important factor of the global economy development is its digitalization. The degree of introduction of technologies determines the overall level of national economy competitiveness. In this context, the research studies modern approaches to the definition of the digital economy and analyzes the digital economy development of the Eurasian Economic Union (the EAEU) countries. Therefore, the article, first, characterizes the features and challenges of the digital economy as a new socio-economic system. Second, it investigates the development of digital economy in the EAEU countries by analyzing the statistical data and indices and identifies the potential of the EAEU countries in this field. Specifically, a rating assessment is made based on the E-Government Development Index, the E-participation Index, the ICT Development Index, the Network Readiness Index, and the Global Cybersecurity Index. The research has showed that there are currently conditions for the development of the digital economy of the EAEU countries and the strengthening of cooperation between them in this field. The advantages of Russia are not total, and Belarus, Kazakhstan and Armenia have the best result in a number of indicators among the EAEU countries. In 2017 the "Main Directions for Implementing the Digital Agenda of the Eurasian Economic Union Until 2025" were approved by the Supreme Eurasian Economic Council. This document includes the following directions: digital transformation of economic sectors and cross-sectoral transformation, digital transformation of the goods markets, services, capital and labor, digital transformation of management processes by integration processes, the development of digital infrastructure and ensuring the security of digital processes. In addition, a number of projects aimed at creating a single digital space are being implemented. This article extends the knowledge about the digital economy development of the EAEU countries, their potential in this area in terms of the implementation of the joint digital agenda.
\end{abstract}

Key words: digital economy, the Eurasian Economic Union (EAEU), E-Government Development Index, E-participation Index, ICT Development Index, Network Readiness Index, Global Cybersecurity Index, potential for the implementation of a joint digital agenda by the EAEU countries.

Citation. Sidorova E.A. Features of the Digital Economy Development in the EAEU Countries. Vestnik Volgogradskogo gosudarstvennogo universiteta. Ekonomika [Journal of Volgograd State University. Economics], 2021, vol. 23, no. 3, pp. 123-137. (in Russian). DOI: https://doi.org/10.15688/ek.jvolsu.2021.3.11

УДК 339.9

Дата поступления статьи: 14.05.2021

ББК 65.5

Дата принятия статьи: 28.05.2021

\section{ОСОБЕННОСТИ РАЗВИТИЯ ЦИФРОВОЙ ЭКОНОМИКИ В СТРАНАХ ЕВРАЗИЙСКОГО ЭКОНОМИЧЕСКОГО СОЮЗА}

\footnotetext{
Екатерина Александровна Сидорова

Международная академия бизнеса и новых технологий, г. Ярославль, Российская Федерация

Аннотация. Важнейшим фактором развития современной глобальной экономики является ее цифровизация. Степень внедрения соответствующих технологий во многом определяет общий уровень конкурентоспособности страны, поскольку они позволяют экономическим субъектам сокращать трансакционные издержки и осуществлять более эффективное взаимодействие между собой. Поэтому целью работы является исследование современных подходов к определению цифровой экономики и анализ особенностей развития цифровой экономики в странах ЕАЭС. В этой связи в статье, во-первых, раскрываются особенности и
} 
вызовы цифровой экономики как новой социально-экономической системы. Во-вторых, в несколько этапов исследуется развитие информационной экономики стран ЕАЭС. Вначале была проведена соответствующая рейтинговая оценка каждой страны объединения с помощью отдельных международных индексов. Далее рассчитана общая позиция интеграционного объединения ЕАЭС по каждому рейтингу. Кроме того, на основе статистических данных сравнивается фактическое состояние развития цифровой экономики Армении, Беларуси, Казахстана, Кыргызстана и России и выявляется потенциал сотрудничества между странами. В ходе исследования выявлено, что в настоящее время существуют условия для развития цифровой экономики стран ЕАЭС и усиления сотрудничества между ними в данной сфере. Преимущества России не носят безраздельно доминирующего характера. По отдельным международным рейтингам и статистическим показателям наилучшие результаты демонстрируют также Беларусь, Казахстан, Армения. В 2017 г. были утверждены «Основные направления реализации цифровой повестки Евразийского экономического союза до 2025 года», к которым отнесены следующие направления: цифровая трансформация отраслей экономики и кросс-отраслевая трансформация, цифровая трансформация рынков товаров, услуг, капитала и рабочей силы, цифровая трансформация процессов управления интеграционными процессами, развитие цифровой инфраструктуры и обеспечение защищенности цифровых процессов. В настоящее время уже реализуются отдельные проекты, которые направлены на создание единого цифрового пространства. Данная статья расширяет знания об особенностях развития и потенциала цифровой экономики стран ЕАЭС.

Ключевые слова: цифровая экономика, Евразийский экономический союз (ЕАЭС), индекс развития электронного правительства, индекс электронного участия, индекс развития информационно-коммуникационных технологий, индекс сетевой готовности, глобальный индекс по кибербезопасности, потенциал реализации совместной цифровой повестки странами ЕАЭС.

Цитирование. Сидорова Е. А. Особенности развития цифровой экономики в странах Евразийского экономического союза // Вестник Волгоградского государственного университета. Экономика. - 2021. - Т. 23, № 3. - C. 123-137. - DOI: https://doi.org/10.15688/ek.jvolsu.2021.3.11

\section{Введение. Постановка проблемы}

Цифровизация экономики и внедрение соответствующих технологий является естественным, закономерным и неизбежным процессом, а потому его изучение в настоящее время является как никогда актуальным. По различным оценкам, цифровая экономика несет в себе огромные изменения для большинства отраслей. Это вызвано тем, что информационные платформы и ресурсы существенно изменяют бизнесмодели, повышая их конкурентоспособность. Вклад цифровых проектов и инициатив может составить до 11 \% ожидаемого совокупного роста ВВП ЕАЭС к 2025 г., считают эксперты Всемирного банка, но для этого необходимо обеспечить синхронизацию усилий стран Союза по реализации цифровой повестки. Переход к цифровой экономике рассматривается ЕАЭС в качестве ключевой движущей силы экономического роста. Для этого решением Высшего Евразийского экономического совета были утверждены План мероприятий по реализации Основных направлений развития механизма «единого окна» в системе регулирования внешнеэкономической деятельности (от 8 мая 2015 г.); Основные направления реализации цифровой повест- ки Евразийского экономического союза до 2025 года (от 11 октября 2017 г.); Концепция трансграничного информационного взаимодействия (от 9 августа 2019 г.).

Работ, посвященных развитию цифровой экономики в рамках ЕАЭС, не так много. Особо стоит выделить информационно-аналитический отчет «Анализ мирового опыта развития промышленности и подходов к цифровой трансформации промышленности государств членов Евразийского экономического союза», подготовленный Департаментом промышленной политики Евразийской экономической комиссии в январе 2017 г., Обзор Всемирного банка «Цифровая повестка Евразийского экономического союза до 2025 года: перспективы и рекомендации» [Цифровая повестка ... , 2018], а также сборник «Цифровая повестка ЕАЭС 2016-2019-2025» [Цифровая повестка ... , 2019], подготовленный Евразийской экономической комиссией в 2019 году. Вместе с тем остается немало вопросов для дальнейшего изучения.

\section{Цель исследования}

Целью работы является исследование современных подходов к определению цифро- 
вой экономики и анализ особенностей развития цифровой экономики в странах ЕАЭС. Для достижения поставленной цели в статье, во-первых, раскрываются особенности и вызовы цифровой экономики как новой социально-экономической системы; во-вторых, в несколько этапов исследуется развитие информационной экономики стран ЕАЭС. Вначале была проведена соответствующая рейтинговая оценка каждой страны объединения с помощью отдельных международных индексов. Далее рассчитана общая позиция интеграционного объединения ЕАЭС по каждому рейтингу. Кроме того, на основе статистических данных сравнивается фактическое состояние развития цифровой экономики Армении, Беларуси, Казахстана, Кыргызстана и России и выявляется потенциал сотрудничества между странами.

\section{Результаты и обсуждение}

\section{Особенности и вызовы}

\section{цифровой экономики как новой} социально-экономической системы

Как указано в докладе Всемирного экономического форума 2016 г., посвященного развитию глобальных информационных технологий, мир стоит на пороге четвертой промышленной революции. Она определяется не каким-либо конкретным набором новых технологий, а, скорее, переходом к новым системам на базе вновь созданной инфраструктуры. По мнению основателя и президента Всемирного экономического форума К. Шваба, все новые достижения имеют одну общую особенность: они эффективно используют всепроникающую силу цифровых и информационных технологий [The Global ..., 2016]. В связи со значительными преобразующими возможностями данных технологий возникла и активно развивается в настоящее время концепция цифровой экономики.

Сам термин «цифровая экономика» впервые был употреблен в 1995 г. американским ученым из Массачусетского университета Н. Негропонте для разъяснения коллегам преимуществ новой экономики в сравнении со старой в связи с интенсивным развитием информационно-коммуникационных технологий (ИКТ) [Юдина, 2016, с. 13]. По опреде- лению Всемирного банка, цифровая экономика - система экономических, социальных и культурных отношений, основанных на использовании цифровых информационно-коммуникационных технологий. В утвержденной в России «Стратегии развития информационного общества Российской Федерации на 2017-2030 годы» дано следующее определение цифровой экономики: «Цифровая экономика - это хозяйственная деятельность, в которой ключевым фактором производства являются данные в цифровом виде, обработка больших объемов и использование результатов анализа которых по сравнению с традиционными формами хозяйствования позволяют существенно повысить эффективность различных видов производства, технологий, оборудования, хранения, продажи, доставки товаров и услуг» [Стратегия ..., 2017]. Авторы книги «Введение в “Цифровую” экономику» утверждают, что «цифровая» (электронная) экономика - это экономика, характерной особенностью которой является максимальное удовлетворение потребностей всех ее участников за счет использования информации, в том числе персональной. Это становится возможным благодаря развитию информационно-коммуникационных и финансовых технологий, а также доступности инфраструктуры, вместе обеспечивающих возможность полноценного взаимодействия в гибридном мире всех участников экономической деятельности: субъектов и объектов процесса создания, распределения, обмена и потребления товаров и услуг [Введение ..., 2017, c. 12]. Доктор экономических наук, член-корреспондент РАН В.В. Иванов дает наиболее широкое определение: «Цифровая экономика - это виртуальная среда, дополняющая нашу реальность» [Иванов, 2015]. Профессор РАН, доктор технических наук Р.В. Мещеряков считает, что к термину «цифровая экономика» имеются два подхода (см. рисунок). Первый подход - «классический»: цифровая экономика - это экономика, основанная на цифровых технологиях, при этом правильнее характеризовать исключительно область электронных товаров и услуг. Второй подход - «расширенный»: цифровая экономика - это экономическое производство с использованием цифровых технологий [Савчук и др., 2011]. 

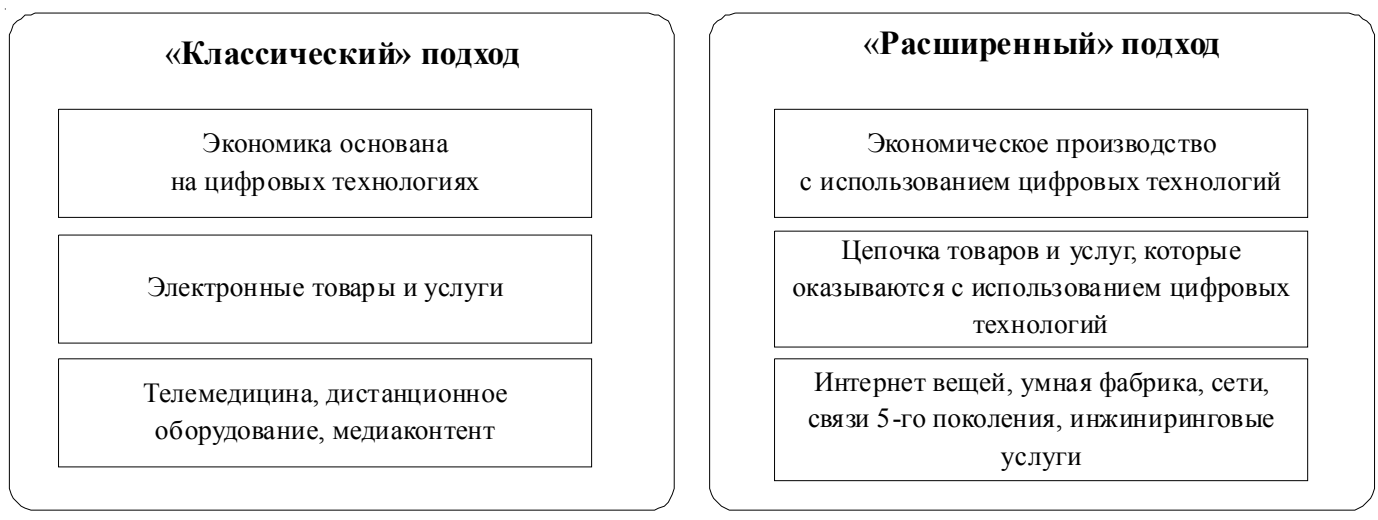

Рисунок. Два подхода к определению понятия «цифровая экономика»

Примечание. Составлено автором.

Таким образом, можно утверждать, что цифровая экономика - это система отношений и хозяйственная деятельность, которая тесно связана с интенсивным развитием информационно-коммуникационных технологий, что позволяет существенно повысить ее эффективность. Фактически все сферы человеческой жизнедеятельности (экономическая, социальная, политическая, культурная, социальная и др.) в той или иной мере трансформируются благодаря открытию и развитию ИКТ. При этом под цифровой трансформацией экономики понимается проявление качественных, революционных изменений, заключающихся не только в отдельных цифровых преобразованиях, но и в принципиальном изменении структуры экономики, в переносе центров создания добавленной стоимости в сферу выстраивания цифровых ресурсов и сквозных цифровых процессов. В результате цифровой трансформации рождается новый технологический уклад, возникают новые отрасли экономики [Цифровая повестка ..., 2018].

Можно выделить основные характеристики цифровой экономики (табл. 1).

В Программе «Цифровая экономика Российской Федерации» [Программа ..., 2017] указано, что цифровая экономика представлена тремя следующими уровнями, которые в своем тесном взаимодействии влияют на жизнь граждан и общества в целом:

- рынки и отрасли экономики (сферы деятельности), где осуществляется взаимодействие конкретных субъектов (поставщиков и потребителей товаров, работ и услуг);

- платформы и технологии, где формируются компетенции для развития рынков и отраслей экономики (сфер деятельности);

- среда, которая создает условия для развития платформ и технологий, эффективного взаимодействия субъектов рынков и отраслей экономики (сфер деятельности) и ох-

\section{Характеристики цифровой экономики}

\begin{tabular}{|l|l|}
\hline \multicolumn{1}{|c|}{ Наименование } & \multicolumn{1}{c|}{ Характеристика } \\
\hline Характер экономики & Сетевая \\
\hline Характер развития экономики & Инновационный \\
\hline Движущие силы экономики & $\begin{array}{l}\text {-знания; } \\
- \text { индивидуумы }\end{array}$ \\
\hline Сырье & Информация \\
\hline Основные инструменты & $\begin{array}{l}\text { интегрированные цифровые платформы; } \\
- \text { искусственный интеллект }\end{array}$ \\
\hline Ведущий сектор производства & Информационно-коммункационные технологии \\
\hline Основной тип хозяйственного взаимодействия & Кооперация \\
\hline Ведущий способ координации & Совещательная \\
\hline Основание экономической власти & Положение в иерархии поля взаимодействия \\
\hline
\end{tabular}

Примечание. Составлено автором по: [Паньшин, 2019; Устюжанина и др., 2020]. 
ватывает нормативное регулирование, информационную инфраструктуру, кадры и информационную безопасность.

По оценкам Всемирного экономического форума, цифровизация несет огромный потенциал для бизнеса и общества и может принести дополнительно более 30 трлн долл. США доходов для мировой экономики в течение ближайших лет (до 2025 года). Одним из пионеров цифровизации и главным идеологом концепции индустрии 4.0 является Германия (2011 г.). Кроме того, цифровые стратегии утвердили более чем в 30 странах ЕС, Китае «Интернет плюс» (2015 г.), Индии - «Цифровая Индия» (2015 г.), Японии - «Общество 5.0» (2016 г.) и др. Ведущими странами мира прилагаются определенные усилия также по выработке «единых цифровых повесток»: в Европейском союзе была запущена специальная инициатива «Цифровая Европа»; в ОЭСР Стратегия общего цифрового рынка; в рамках Транстихоокеанского партнерства (ТТП) 13-я и 14-я главы Соглашения, касающиеся телекоммуникаций и электронной коммерции; в АСЕАН - Мастер-план 2015 «Информационно-коммуникационных технологий»; в СНГ - Стратегия сотрудничества государств - участников СНГ в построении и развитии информационного общества на период до 2025 года и План действий по ее реализации [Анализ ... , 2017].

Во время чрезвычайной ситуации COVID-19 ИКT сыграли жизненно важную роль в укреплении здоровья и безопасности людей, а также в поддержании функционирования экономики и общества. Цифровые государственные технологии, благодаря обмену информацией и предоставлению онлайнуслуг, поддерживали связь между правительствами и людьми во время вспышки болезни. Цифровые технологии также позволяют правительствам быстро принимать политические решения на основе аналитических данных в режиме реального времени, расширять возможности местных органов власти для улучшения координации и предоставлять услуги, основанные на фактических данных, тем, кто в них больше всего нуждается [United Nations E-Government Surveys ..., 2020].

В то же время в результате цифровизации на национальном и международном уров- нях возникают новые и усиливаются существующие отдельные риски общественного и экономического развития. Один из крупнейших исследователей информационного общества профессор М. Кастельс девятый раздел своей книги «Галактика Интернет: Размышления об Интернете, бизнесе и обществе» посвятил проблеме «цифрового разрыва» в глобальной перспективе. Ученый пишет, что «на протяжении 1990-х годов, отмеченных бурной революцией в области информационных технологий, возникновением экономики нового типа и распространением Интернета, мир стал свидетелем значительного углубления имущественного неравенства, поляризации, бедности и социальной сегрегации» [Кастельс, 2004, c. 303]. Главный цифровой разрыв определяется не количеством подключений к Интернету, а последствиями как подключения, так и отсутствия такового. При этом «цифровой разрыв» не будет сокращаться, поскольку, «когда массы наконец получат доступ к Интернету... мировые элиты уже окажутся в более высоких сферах киберпространства» [Кастельс, 2004, с. 294-295]. Для новой модели развития необходимо преодолеть планетарный «цифровой разрыв» одним прыжком с помощью экономики, способной самообучаться и генерировать знания, основанной на Интернете, который получит поддержку от легитимных и эффективных политических институтов.

В нормативно-правовом акте ЕАЭС «Основные направления реализации цифровой повестки Евразийского экономического союза до 2025 года» [Решение ...] указаны следующие вызовы для Союза в результате глобальной цифровой трансформации:

- без развития цифровой экономики и совместной реализации проектов в рамках цифровой повестки государства - члены ЕАЭС лишают себя новых возможностей, оставаясь в рамках традиционных процессов, отношений и связей;

- происходит высвобождение огромных трудовых ресурсов и возникновение дисбалансов во всех отраслях экономик государств членов ЕАЭС;

- происходит отток трудовых ресурсов и потребителей в цифровые экономики третьих стран и в цифровые экосистемы глобальных цифровых платформ; 
- возникает необходимость более надежной институциональной формы защиты персональных данных с соблюдением баланса защиты в условиях их трансграничного обмена;

- происходит обесценивание традиционных активов и хозяйствующих субъектов государств - членов ЕАЭС, не прошедших цифровые преобразования и трансформацию.

Для оценки развития цифровой экономики в странах ЕАЭС в работе проведен анализ ряда международных индексов, которые одновременно включают все государства данного интеграционного объединения.

\section{Анализ развития цифровой экономики в странах ЕАЭС на основе \\ отдельных международных индексов}

Индекс развития электронного правительства (E-Government Development Index, EGDI) составляется раз в два года Департаментом экономического и социального развития ООН. В соответствии с методикой формирования данного индекса оценка развития электронного правительства проводится по показателям трех субиндексов: возможность и качество онлайн-сервисов, человеческий капитал, развитость телекоммуникационной инфраструктуры. Ранжирование стран приводится только по агрегированному индексу. Индекс электронного участия (E-participation Index, EPI) - это показатель развития сервисов активного взаимодействия между гражданами и государством, или индекс Gov 2.0, который выводится в качестве дополнительного индекса к индексу электронного правительства ООН. В настоящее время индекс охватывает в общей сложности 193 экономики мира. Лидером глобального рейтинга по уровню развития электронного правительства в 2020 г. является Дания (значение индекса - 0,9758). В первую пятерку также вошли Республика Корея $(0,956)$, Эстония $(0,9473)$, Финляндия $(0,9452)$ и Австралия $(0,9432)$. Во всем мире наблюдается продолжительный рост участия в развитии электронного правительства, причем $65 \%$ государств - членов ЕАЭС в настоящее время входят в группу с высоким или очень высоким уровнем EGDI [United Nations E-Government Surveys ..., 2020].

Из таблицы 2 следует, что из стран ЕАЭС в 2020 г. наилучший показатель индекса развития электронного правительства имел Казахстан, который занял 29-е место в рейтинге. С 2018 г. страна поднялась на 10 позиций за счет роста значений всех субиндексов, но прежде всего - субиндекса «Развитость ИКТ-инфраструктуры» (+0,1301 п.). Россия в 2020 г. заняла 36-е место, потеряв с 2018 г. 4 позиции в рейтинге. При этом стоит отметить, что снизился только субиндекс «Возможность и качество онлайн-сервисов» на 0,0991 п. Беларусь в 2020 г. заняла 40-е место, снизившись на 2 места в рейтинге с 2018 г., прежде всего за счет падения значения субиндекса «Возможность и качество онлайнсервисов» $(-0,0302$ п.). При этом в стране с 2017 г. реализуется Государственная стратегия устойчивого социального и экономического

Таблича 2

Индекс развития электронного правительства (EGDI) и Индекс электронного участия (ЕPI) стран ЕАЭС в 2020 г.

\begin{tabular}{|c|c|c|c|c|c|c|c|c|}
\hline Страна & $\begin{array}{c}\text { Рейтинг } \\
\text { страны } \\
\text { по EGDI, } \\
\text { в скобках - } \\
\text { в } 2018 \text { г. }\end{array}$ & $\begin{array}{l}\text { Значе- } \\
\text { ние } \\
\text { EGDI }\end{array}$ & $\begin{array}{c}\Delta \text { EGDI } \\
\text { с } 2018 \\
\text { по } 2020 \text { г. }\end{array}$ & $\begin{array}{c}\text { Значение } \\
\text { ЕРI } \\
\text { (в скобках } \\
\text { указано ме- } \\
\text { сто страны } \\
\text { в данном } \\
\text { рейтинге) }\end{array}$ & $\begin{array}{c}\Delta \text { EPI } \\
\text { c } 2018 \\
\text { по } 2020 \text { г. }\end{array}$ & $\begin{array}{c}\text { Субиндекс } \\
\text { «Возмож- } \\
\text { ность и каче- } \\
\text { ство онлайн- } \\
\text { сервисов» }\end{array}$ & $\begin{array}{c}\text { Субиндекс } \\
\text { «Человече- } \\
\text { ский капи- } \\
\text { тал» }\end{array}$ & $\begin{array}{c}\text { Субиндекс } \\
\text { «Развитость } \\
\text { телекоммуни- } \\
\text { кационной ин- } \\
\text { фраструктуры» }\end{array}$ \\
\hline Казахстан & $29(39)$ & 0,8375 & 0,0778 & $0,881(26)$ & 0,0439 & 0,9235 & 0,8866 & 0,7024 \\
\hline Россия & $36(32)$ & 0,8244 & 0,0275 & $0,869(27)$ & $-0,0523$ & 0,8176 & 0,8833 & 0,7723 \\
\hline Беларусь & $40(38)$ & 0,8084 & 0,0443 & $0,75(57)$ & $-0,132$ & 0,7059 & 0,8912 & 0,8281 \\
\hline Армения & $68(87)$ & 0,7136 & 0,1192 & $0,75(57)$ & 0,1826 & 0,7 & 0,7872 & 0,6536 \\
\hline Кыргызстан & $83(91)$ & 0,6749 & 0,0914 & $0,7143(66)$ & 0,1308 & 0,6471 & 0,7873 & 0,5902 \\
\hline
\end{tabular}

Примечание. Составлено автором по: [United Nations E-Government Surveys ..., 2020]. 
развития на период до 2030 года, в состав которой входят несколько инициатив по развитию ИКТ в разных секторах экономики. Армения в 2020 г. заняла 68 -е место, поднявшись в рейтинге на 19 позиций. Имел место рост значений всех субиндексов рейтинга, но прежде всего - субиндекса «Развитость ИКТ-инфраструктуры» $(+0,1876$ п.). Кыргызстан в 2020 г. занял 83-е место (наименьший показатель индекса развития электронного правительства из стран ЕАЭС), поднявшись на 8 позиций в рейтинге за счет роста значений всех субиндексов, но прежде всего - субиндекса «Развитость ИКТ-инфраструктуры» (+0,2484 п.). При этом наиболее высоким показателем стран ЕАЭС, за исключением Казахстана, является субиндекс «Человеческий капитал», у Казахстана - субиндекс «Возможность и качество онлайн-сервисов». Наболее низким показателем стран ЕАЭС, за исключением Беларуси, является субиндекс «Развитость ИКТ-инфраструктуры», у Беларуси - «Возможность и качество онлайн-сервисов». Стоит особо подчеркнуть, что у всех стран ЕАЭС значение индекса выше среднемирового показателя, который в 2020 г. составил 0,60. Причем Беларусь, Казахстан и Россия вошли в группу с очень высоким EGDI, а Армения и Кыргызстан - в группу с высоким EGDI. C 2018 г. значение данного индекса у всех стран ЕАЭС повысилось, но в большей степени - у Армении и Кыргызстана.

По индексу электронного участия в 2020 г. первое место занимают Эстония, США, Республика Корея (значение индекса $-1,0000$ ). Самый высокий показатель индекса среди стран ЕАЭС демонстрирует Казахстан $(0,881)$, заняв 26-е место в рейтинге; самый низкий показатель имеет Кыргызстан - 66-е место.
Армения, Беларусь, Казахстан и Россия вошли в группу с очень высоким EPI, а Кыргызстан - в группу с высоким ЕРІ. Тем не менее с 2018 г. значение данного индекса у Беларуси и России снизилось. У всех остальных стран ЕАЭС наблюдался рост индекса, но в большей степени - у Армении и Кыргызстана.

Индекс развития информационнокоммуникационных технологий (ICT Development Index, IDI) также называют индексом развития ИКТ. Индекс рассчитывается ежегодно по методике Международного союза электросвязи, специализированного подразделения $\mathrm{OOH}$, определяющего мировые стандарты в области ИКТ. Данный индекс строится на основе трех субиндексов: доступ к ИКТ, использование ИКТ, практические навыки в области ИКТ [Measuring the Information ..., 2017, vol. 1]. Индекс развития ИКТ в 2017 г. охватывает 176 стран мира: первое место занимает Исландия (значение Индекса - 8,98), за ней следуют Республика Корея и Швейцария.

Из таблицы 3 следует, что из стран ЕАЭС в 2017 г. наилучший показатель индекса развития ИКТ имела Беларусь, которая единственная находится в верхнем квартиле индекса и не изменила своих позиций в рейтинге - 32-е место. Россия, Казахстан и Армения ухудшили свои позиции: Россия - на 2 позиции, Казахстан и Армения - на 1 позицию. Кыргызстан поднялся на 1 позицию в рейтинге, но при этом имеет наименьший показатель индекса развития ИКТ - 109-е место. Наиболее высоким показателем стран ЕАЭС, за исключением Казахстана, является субиндекс практических навыков в области ИКТ, у Казахстана - субиндекс доступа к ИКТ. Наболее низким показателем стран

Индекс развития ИКТ (IDI) в странах ЕАЭС в 2017 г.

\begin{tabular}{|c|c|c|c|c|c|c|}
\hline $\begin{array}{c}\text { Рейтинг } \\
\text { страны по IDI, } \\
\text { в скобках } \\
\text { в 2016 г. }\end{array}$ & Страна & $\begin{array}{c}\text { Значение } \\
\text { IDI }\end{array}$ & $\begin{array}{c}\Delta \text { IDI } \\
\mathbf{c ~ 2 0 1 6 ~ п о ~} \\
\mathbf{2 0 1 7} \text { г. }\end{array}$ & $\begin{array}{c}\text { Субиндекс } \\
\text { доступа } \\
\text { к ИКT }\end{array}$ & $\begin{array}{c}\text { Субиндекс } \\
\text { использования } \\
\text { ИКТ }\end{array}$ & $\begin{array}{c}\text { Субиндекс } \\
\text { практических } \\
\text { навыков } \\
\text { в области Икт }\end{array}$ \\
\hline $32(32)$ & Беларусь & 7,55 & 0,29 & 7,87 & 6,54 & 8,93 \\
\hline $45(43)$ & Россия & 7,07 & 0,12 & 7,23 & 6,13 & 8,62 \\
\hline $52(51)$ & Казахстан & 6,79 & 0,22 & 7,55 & 5,69 & 7,48 \\
\hline $75(74)$ & Армения & 5,76 & 0,16 & 6,52 & 4,42 & 6,94 \\
\hline $109(110)$ & Кыргызстан & 4,37 & 0,38 & 4,54 & 2,91 & 6,96 \\
\hline
\end{tabular}

Примечание. Составлено автором по: [Measuring the Information ... , 2017, vol. 2]. 
ЕАЭС является субиндекс использования ИКТ. У Армении, Беларуси, Казахстана и России значение индекса выше среднемирового показателя, которое в 2017 г. составило 5,11 . За последний оцениваемый период у всех стран ЕАЭС наблюдался рост индекса развития ИКТ, но в большей степени - у Беларуси и Кыргызстана.

Индекс сетевой готовности (Network Readiness Index, NRI), первоначально созданный в 2002 г. Всемирным экономическим форумом, был переделан в 2019 г. его основателями и соредакторами Soumitra Dutta и Bruno Lanvin, чтобы отразить, как технологии и люди должны быть интегрированы в эффективную структуру управления. В настоящее время индекс охватывает в общей сложности 134 экономики; состоит из 4 субиндексов: развитие технологий; использование ИКТ населением на разных уровнях; развитие национальной среды для участия в сетевой экономике; воздействие ИКТ на экономику, качество жизни и достижение целей в области устойчивого развития (ЦУР). По индексу сетевой готовности в 2020 г. 1-е место заняла Швеция (значение индекса - 82,75), далее - Дания и Сингапур [The Network Readiness Index ..., 2020].

Из таблицы 4 следует, что из стран ЕАЭС в 2020 г. наилучший показатель индекса сетевой готовности имеет Россия - 48-е место. По сравнению с 2019 г. Армения поднялась на 7 позиций в рейтинге, заняв 55-е место; Казахстан - на 4 позиции, заняв 56-е место в рейтинге. Беларусь располагается на 65-м месте, потеряв с 2019 г. 4 позиции в рейтинге. Наименьший показатель индекса сетевой готовности имеет Кыргызстан - 94-е место. Наиболее высоким показателем Беларуси, Казах- стана и России является субиндекс развития национальной среды для участия в сетевой экономике, у Армении - субиндекс использования ИКТ населением на разных уровнях, у Кыргызстана - субиндекс воздействия ИКТ на экономику, качество жизни и достижение ЦУР. Наболее низким показателем стран ЕАЭС является субиндекс развития технологий. Стоит отметить, что у Армении, Казахстана и России значение индекса выше среднемирового показателя, которое в 2020 г. составило 49,5. Кроме того, данные страны демонстрируют рост индекса сетевой готовности с 2019 г., а Беларусь и Кыргызстан снижение.

Глобальный индекс по кибербезопасности (Global Cybersecurity Index, GCI). C 2014 г. Международный союз электросвязи составляет рейтинг стран по индексу кибербезопасности. При составлении рейтинга принимаются во внимание пять основных критериев: законодательная база, технические и организационные мероприятия в области кибербезопасности, сотрудничество, в том числе на международном уровне, а также создание потенциала для развития сферы. В рейтинг входят 194 страны. По состоянию на 2018 г. 58 \% стран-участниц имеют национальную стратегию в области кибербезопасности, в то время как в предыдущей редакции рейтинга таких насчитывалось всего $50 \%$. Кроме того, $91 \%$ государств имеют законодательство в этой сфере, хотя в 2017 г. таких стран было всего $79 \%$. В 2018 г. в общем рейтинге лидерами по реализации норм в сфере кибербезопасности, а также мер борьбы с киберпреступлениями и спамом оказались Великобритания, США, Франция [Global Cybersecurity Index, 2017].

Таблица 4

Индекс сетевой готовности (NRI) в странах ЕАЭС в 2020 г.

\begin{tabular}{|c|c|c|c|c|c|c|c|}
\hline $\begin{array}{c}\text { Позиция } \\
\text { в рейтинге } \\
\text { в скобках } \\
\text { в 2019 г. }\end{array}$ & Страна & $\begin{array}{c}\text { Значе- } \\
\text { ние NRI }\end{array}$ & $\begin{array}{c}\Delta \text { NRI } \\
\mathbf{c 2 0 1 9} \\
\text { по 2020 г. }\end{array}$ & $\begin{array}{c}\text { Развитие } \\
\text { техноло- } \\
\text { гий }\end{array}$ & $\begin{array}{c}\text { Использова- } \\
\text { ние ИкT } \\
\text { населением } \\
\text { на разных } \\
\text { уровнях }\end{array}$ & $\begin{array}{c}\text { Развитие } \\
\text { национальной } \\
\text { среды для уча- } \\
\text { стия в сетевой } \\
\text { экономике }\end{array}$ & $\begin{array}{c}\text { Воздействие ИКТ } \\
\text { на экономику, } \\
\text { качество жизни } \\
\text { и достижение } \\
\text { ЦУР }\end{array}$ \\
\hline $48(48)$ & Россия & 54,23 & 4,07 & 46,62 & 59,68 & 56,98 & 53,65 \\
\hline $55(62)$ & Армения & 51,91 & 2,07 & 50,19 & 54,09 & 52,36 & 50,99 \\
\hline $56(60)$ & Казахстан & 51,38 & 0,7 & 39,64 & 51,33 & 58,55 & 56,01 \\
\hline $65(61)$ & Беларусь & 49,16 & $-1,18$ & 39,05 & 48,94 & 54,47 & 54,17 \\
\hline $94(91)$ & Кыргызстан & 38,60 & $-1,12$ & 26,22 & 35,59 & 45,29 & 47,31 \\
\hline
\end{tabular}

Примечание. Составлено автором по: [The Network Readiness Index ..., 2020]. 
Из таблицы 5 следует, что из стран ЕАЭС в 2018 г. наилучший показатель индекса имела Россия - 26-е место, которая, однако, с 2017 г. потеряла 16 позиций в рейтинге. При этом Казахстан и Армения значительно улучшили свои позиции в рейтинге - на 42 и 31 позиции соответственно. Наименьший показатель индекса имеет Кыргызстан - 111-е место. Необходимо особо подчеркнуть, что значения отдельных субиндексов из стран ЕАЭС представлены только у России и Казахстана, у которых наиболее высокое значение имеет субиндекс «Законодательная база», а наиболее низкое значение - субиндекс «Сотрудничество». Лишь Казахстан и Россия вошли в группу с высоким значением GCI. C 2017 г. данный индекс у Армении, Казахстана и России вырос. У остальных стран ЕАЭС наблюдалось его снижение.

На основе анализа групп показателей развития цифровой экономики в отдельных международных рейтингах, представленного в таблице 6, можно сделать следующие выводы:

- только индекс сетевой готовности (NRI) включает пять из семи групп показателей;

- четыре из пяти приведенных индексов учитывают уровень развития человеческого капитала стран: EGDI, IDI, NRI, GCI;

- три из пяти индексов учитывают уровень развития сервисов взаимодействия между гражданами и государством (EGDI, EPI, $\mathrm{NRI)} \mathrm{и} \mathrm{уровень} \mathrm{развития} \mathrm{телекоммуникацион-}$ ной инфраструктуры (EGDI, IDI, NRI); остальные группы показателей учтены не более, чем в двух индексах;

- явное воздействие цифровизации общества на экономическую и социальную сферы оценивает только индекс сетевой готовности (NRI).

Таким образом, приведенные международные рейтинги учитывают только отдельные группы показателей развития цифровой

Глобальный индекс по кибербезопасности (GCI) в странах ЕАЭС в 2017 г.

\begin{tabular}{|c|c|c|c|}
\hline $\begin{array}{c}\text { Позиция в рейтинге, } \\
\text { в скобках - в 2017 г. }\end{array}$ & Страна & Значение GCI & $\begin{array}{c}\Delta \mathbf{G C I} \text { с 2017 } \\
\text { по 2018 г. }\end{array}$ \\
\hline $26(10)$ & Россия & 0,836 & 0,048 \\
\hline $40(82)$ & Казахстан & 0,778 & 0,426 \\
\hline $69(39)$ & Беларусь & 0,578 & $-0,014$ \\
\hline $79(110)$ & Армения & 0,495 & 0,299 \\
\hline $111(96)$ & Кыргызстан & 0,254 & $-0,016$ \\
\hline
\end{tabular}

Примечание. Составлено автором по: [Global Cybersecurity Index, 2017].

Таблица 6

\section{Анализ групп показателей развития цифровой экономики в отдельных международных рейтингах}

\begin{tabular}{|c|c|c|c|c|c|c|}
\hline № ПI/II & Группы показателей & EGDI & EPI & IDI & NRI & GCI \\
\hline 1 & Развитие онлайн-сервисов & + & - & - & + & - \\
\hline 1.1 & $\begin{array}{l}\text { В том числе развитие сервисов взаимодействия между граж- } \\
\text { данами и государством }\end{array}$ & + & + & - & + & - \\
\hline 2 & Человеческий капитал & + & - & + & + & + \\
\hline 3 & Развитие информационно-коммуникационной инфраструктуры & + & - & + & + & - \\
\hline 4 & $\begin{array}{l}\text { Развитие национальной среды для участия в цифровой эконо- } \\
\text { мике, в том числе законодательной базы }\end{array}$ & - & - & - & + & + \\
\hline 5 & $\begin{array}{l}\text { Воздействие ИКТ на экономическую и социальную сферы, дос- } \\
\text { тижение ЦУР }\end{array}$ & - & - & - & + & - \\
\hline 6 & $\begin{array}{l}\text { Технические и организационные мероприятия в области кибер- } \\
\text { безопасности }\end{array}$ & - & - & - & - & + \\
\hline 7 & $\begin{array}{l}\text { Деятельность для развития данной сферы на международном } \\
\text { уровне }\end{array}$ & - & - & - & - & + \\
\hline
\end{tabular}

Примечание. Составлено автором. 
экономики. При этом наибольшее количество разных показателей охватывает индекс сетевой готовности (NRI). Однако ни один международный рейтинг не учитывает особенности конкретных стран.

Для более объективного представления данных следует вычислить медианный, то есть усредненный глобальный рейтинг стран ЕАЭС с точки зрения развития цифровой экономики. Данная модель была позаимствована у Е.В. Балацкого и Н.А. Екимовой [Балацкий и др., 2011, с. 134], которая применяется ими на первом этапе исследования сравнительной надежности глобальных рейтингов университетов. Авторы утверждают, что при объединении различных рейтингов «включается» закон больших чисел, тем самым усредненная оценка по многим рейтингам дает некий ориентир истинного места. При этом авторы подчеркивают, что полученный медианный рейтинг имеет вспомогательное значение, поэтому его следует воспринимать не в качестве самостоятельного индикатора, а в качестве квазиобъективной оценки рейтингов.

$$
z_{j}=\frac{1}{m} \sum_{i=1}^{m} x_{i j}
$$

где $i$ - индекс рейтинга; $j$ - индекс страны; $j=1, \ldots, N$; $N$ - число анализируемых стран; $m$ - число анализируемых рейтингов; $x_{i j}$ - ранг (место) страны $j$ в рейтинге $i ; z_{j}$-ранг (место) страны $j$ в медианном рейтинге.
В результате применения данной модели страны ЕАЭС с точки зрения развития цифровой экономики были проранжированы следующим образом: 1) Россия (36-е место условно); 2) Казахстан (41-е место условно); 3) Беларусь (53-е место условно); 4) Армения (67-е место условно); 5) Кыргызстан (93-е место условно). Стоит отметить, что в данном случае Россия является явным лидером, а позиции Казахстана, Беларуси и Армении находятся рядом. Кыргызстан значительно отстает от других стран.

Для оценки общей позиции ЕАЭС по каждому рейтингу были использованы два способа:

1) как средневзвешенное значение пропорционально вкладу государства-члена в суммарный ВВП Союза;

2) как среднеарифметическое значение позиций государств - членов Союза, представленных в рейтинге (табл. 7).

Стоит отметить, что при использовании первого способа расчета позиция ЕАЭС выше, чем при использовании второго способа. Дело в том, что в суммарном ВВП Союза более $85 \%$ составляет ВВП России, поэтому в данном случае общая позиция ЕАЭС значительно зависит от позиции России в рейтинге. Однако необходимо осторожно применять результаты расчетов, хотя они все-таки вносят некоторую ясность в диспозицию стран ЕАЭС с точки зрения существующих международных рейтингов развития цифровой экономики стран мира.

Позиция ЕАЭС в отдельных международных рейтингах, характеризующих развитие цифровой экономики

\begin{tabular}{|l|c|c|c|c|c|c|c|}
\hline $\begin{array}{c}\text { Название } \\
\text { международного рейтинга }\end{array}$ & Армения & Беларусь & $\begin{array}{c}\text { Казах- } \\
\text { стан }\end{array}$ & $\begin{array}{c}\text { Кыргыз- } \\
\text { стан }\end{array}$ & Россия & $\begin{array}{c}\text { Позиция } \\
\text { ЕАЭС (1) }\end{array}$ & $\begin{array}{c}\text { Позиция } \\
\text { ЕАЭС (2) }\end{array}$ \\
\hline $\begin{array}{l}\text { Индекс развития электронно- } \\
\text { го правительства, 2020 г. }\end{array}$ & 68 & 40 & 29 & 83 & 36 & 36 & 51 \\
\hline $\begin{array}{l}\text { Индекс электронного участия, } \\
2020 \text { г. }\end{array}$ & 57 & 57 & 26 & 66 & 27 & 28 & 47 \\
\hline Индекс развития ИКТ, 2017 г. & 75 & 32 & 52 & 109 & 45 & 46 & 63 \\
\hline $\begin{array}{l}\text { Индекс сетевой готовности, } \\
2020 \text { г. }\end{array}$ & 55 & 65 & 56 & 94 & 48 & 50 & 64 \\
\hline $\begin{array}{l}\text { Глобальный индекс по кибер- } \\
\text { безопасности, 2018 г. }\end{array}$ & 79 & 69 & 40 & 111 & 26 & 29 & 65 \\
\hline
\end{tabular}

Примечание. Составлено автором; ВВП стран ЕАЭС рассчитан по: [Евразийский экономический союз ..., 2020, с. 14; Прогноз ...]. 


\section{Анализ развития цифровой экономики}

в странах ЕАЭС на основе статистических данных

В связи с вышесказанным в таблице 8 приведены отдельные статистические показатели, характеризующие развитие цифровой экономики в странах ЕАЭС в 2020 г. (или последний период, по которому доступна данная информация), а также выделена позиция России среди государств данного объединения.

Согласно данным таблицы 8 , по трем из семи абсолютных и относительных показателей среди стран ЕАЭС лидирует Россия. Однако по таким показателям, как численность индивидуальных пользователей сети Интернет, экспорт продукции и услуг отрасли ИКТ (в \% от общего объема экспорта) и количество фиксированных телефонных линий на 100 человек населения, Беларусь опережает другие страны ЕАЭС. При этом по такому показателю, как экспорт услуг отрасли ИКТ (в \% от общего объема экспорта услуг), Бе- ларусь и Армения опережают Россию. Стоит отметить, что разрыв между странами почти по всем показателям находится в допустимых пределах для развития кооперации в данной сфере.

В исследовании Всемирного банка «Получение цифровых дивидендов: эффективное использование Интернета для развития в Европе и Центральной Азии» страны делятся на три группы в зависимости от уровня развития цифровых технологий и поддерживающей среды: «зарождения», «перехода» и «трансформации». К странам, где цифровая экономика только зарождается, относятся те, в которых доля пользователей Интернета настолько низка, что они практически не ощущают какихлибо кардинальных изменений, которые несут с собой новые технологии. Страны переходной группы имеют достойный уровень доступа к Интернету, однако в них развитие новых технологий может привести к проблемам изза недостаточного развития определенных «аналоговых» основ. И наконец, страны, входящие в группу трансформации, характеризу-

Таблица 8

\section{Отдельные показатели, характеризующие развитие цифровой экономики} в странах ЕАЭС, 2020 г.

\begin{tabular}{|c|c|c|c|c|c|c|c|c|c|c|}
\hline \multirow[b]{2}{*}{ Показатель } & \multicolumn{5}{|c|}{ Абсолютное значение } & \multicolumn{5}{|c|}{ Относительное значен ие (Россия - 100 \%) } \\
\hline & $\begin{array}{c}\text { Арме- } \\
\text { ния }\end{array}$ & $\begin{array}{l}\text { Бела- } \\
\text { русь }\end{array}$ & \begin{tabular}{|} 
Казах- \\
стан
\end{tabular} & $\begin{array}{l}\text { Кыр- } \\
\text { гыз- } \\
\text { стан }\end{array}$ & Россия & $\begin{array}{c}\text { Арме- } \\
\text { ния }\end{array}$ & $\begin{array}{l}\text { Бела- } \\
\text { русь }\end{array}$ & $\begin{array}{c}\text { Казах- } \\
\text { стан }\end{array}$ & $\begin{array}{l}\text { Кыр- } \\
\text { гыз- } \\
\text { стан }\end{array}$ & Россия \\
\hline $\begin{array}{l}\text { Численность индивидуальных } \\
\text { пользователей сети Интернет, } \\
\text { \% от численности населения } \\
\text { страны }\end{array}$ & 64,7 & 82,8 & 81,9 & 38 & 82,6 & 78,3 & 100,2 & 99,2 & 46 & 100 \\
\hline $\begin{array}{l}\text { Безопасные интернет-серверы в } \\
\text { расчете на } 1 \text { млн чел. численно- } \\
\text { сти населения страны, ед. }\end{array}$ & 587,6 & 7487,5 & 3311,4 & 422,1 & 13322,4 & 4,4 & 56,2 & 24,9 & 3,2 & 100 \\
\hline $\begin{array}{l}\text { Экспорт продукции отрасли } \\
\text { ИКТ, \% от общего объема } \\
\text { Экспорта товаров страны }\end{array}$ & 0,3 & 0,8 & 0,1 & 0,2 & 0,5 & 60 & 160 & 20 & 40 & 100 \\
\hline $\begin{array}{l}\text { Импорт продукции отрасли } \\
\text { ИКТ, \% от общего объема им- } \\
\text { порта товаров страны }\end{array}$ & 5,2 & 3,7 & 5,6 & 5,3 & 9,4 & 55,3 & 39,4 & 59,6 & 56,4 & 100 \\
\hline $\begin{array}{l}\text { Экспорт услуг отрасли ИКТ, } \\
\text { \% от общего объема экспорта } \\
\text { услуг страны }\end{array}$ & 10,5 & 18,4 & 1,8 & 4,8 & 8,1 & 129,6 & 227,2 & 19,2 & 51,2 & 100 \\
\hline $\begin{array}{l}\text { Количество фиксированных } \\
\text { телефонных линий на } 100 \text { че- } \\
\text { ловек населения страны, ед. }\end{array}$ & 15,3 & 47,5 & 17,3 & 4,7 & 22 & 55,9 & 215,9 & 78,6 & 21,4 & 100 \\
\hline $\begin{array}{l}\text { Численность абонентов сото- } \\
\text { вой связи на } 100 \text { человек насе- } \\
\text { ления страны, ед. }\end{array}$ & 122,3 & 122,9 & 138,6 & 134,4 & 164,4 & 74,8 & 74,8 & 84,3 & 81,8 & 100 \\
\hline
\end{tabular}

Примечание. Составлено автором по: [World Development Indicators ..., 2020]. 
ются хорошо развитым телекоммуникационным рынком, но в них могут быть недостаточно развиты некоторые из «аналоговых» основ, что сдерживает положительное влияние новых технологий [Цифровая повестка ... , 2018]. С точки зрения этой классификации страны - члены ЕАЭС (за исключением Кыргызстана, находящегося на этапе «зарождения») находятся в группе «перехода». При верном определении курса трансформации для Кыргызстана открывается возможность скачка в «переходную» группу, а для большинства членов ЕАЭС - в группу лидеров при объединении усилий. Стоит отметить, что наиболее высокий уровень развития цифровых технологий демонстрирует Россия, а наиболее высокий уровень развития поддерживающей среды - Армения.

Таким образом, можно отметить благоприятные условия для развития цифровой экономики стран ЕАЭС и усиления сотрудничества между ними в данной сфере. Прежде всего, разная скорость цифровизации национальных экономик стран - членов ЕАЭС хотя отчасти и имеет место, но не является непреодолимой. По отдельным международным рейтингам и статистическим показателям, кроме России, наилучшие результаты демонстрируют также Беларусь, Казахстан и Армения, что крайне важно для дальнейшего сотрудничества с целью построения единого цифрового пространства. Все страны ЕАЭС имеют высокие показатели развития человеческого капитала и национальной среды, в том числе законодательной базы, для участия в цифировой экономике. Однако с целью стимулирования дальнейшего формирования цифровой экономики стран ЕАЭС необходимо активно поддерживать развитие технологий в этой сфере и информационно-коммуникационной инфраструктуры, причем на частном, государственном и международном уровнях, а также путем проведения совместных мероприятий.

\section{Заключение}

Таким образом, проведенное исследование позволяет утверждать, что цифровая экономика представляет собой систему отношений и хозяйственную деятельность, которая тесно связана с интенсивным разви- тием информационно-коммуникационных технологий, существенно повышающих ее эффективность. Фактически все сферы человеческой жизнедеятельности в той или иной мере трансформируются из-за развития ИКТ. Вместе с тем цифровизация несет как огромный потенциал для стран мировой экономики, так и ряд вызовов общественного и экономического развития.

Относительно стран ЕАЭС в настоящее время существуют условия для развития цифровой экономики и усиления сотрудничества между ними в данной сфере с целью реализации совместной цифровой повестки. Преимущества России не носят безраздельно доминирующего характера. По отдельным международным индексам и статистическим показателям наилучшие результаты демонстрируют также Беларусь, Казахстан и Армения. Все страны ЕАЭС обладают потенциалом с точки зрения цифровой трансформации экономики. Этому способствует утверждение в 20152019 гг. ряда нормативно-правовых документов, и уже в настоящее время предпринимаются отдельные шаги, которые направлены на создание цифрового пространства интеграционного объединения. Вместе с тем необходимо дальнейшее стимулирование развития цифровой экономики стран объединения. По мнению экс-председателя Коллегии ЕЭК Тиграна Саркисяна, существуют «как минимум два подхода к реализации цифровой трансформации экономики. Первый основан на том, что крупные евразийские компании, имеющие свои наработки, масштабируют их на все пространство ЕАЭС. Второй подход подразумевает участие в реализации цифровых инициатив, одобренных ЕЭК, всех стран Союза - так, чтобы была специализация, но при этом каждое государство участвовало в общем проекте. Это позволит странам наращивать определенные цифровые компетенции» [Модели ..., 2021]. Однако выбор остается за странами-участницами.

\section{СПИСОК ЛИТЕРАТУРЫ}

Анализ мирового опыта развития промышленности и подходов к цифровой трансформации промышленности государств-членов Евразийского экономического союза : Информа- 
ционно-аналитический отчет. - М. : Евразийская экономическая комиссия, 2017. - Электрон. текстовые дан. - Режим доступа: http:// www.eurasiancommission.org/ru/act/prom_i agroprom/dep_prom/Pages $/ \% \mathrm{D} 0 \% 9 \mathrm{C} \% \mathrm{D} 0 \%$ BE $\%$ D0\%BD $\%$ D0\%B8\%D1\%82\%D0\%BE\% $\mathrm{D} 1 \% 80 \% \mathrm{D} 0 \% \mathrm{~B} 8 \% \mathrm{D} 0 \% \mathrm{BD} \% \mathrm{D} 0 \% \mathrm{~B} 3 \% 20 \% \mathrm{D} 0 \%$ $\mathrm{B} 8 \% 20 \% \mathrm{D} 0 \% \mathrm{~B} 0 \% \mathrm{D} 0 \% \mathrm{BD} \% \mathrm{D} 0 \% \mathrm{~B} 0 \% \mathrm{D} 0 \%$ $\mathrm{BB} \% \mathrm{D} 0 \% \mathrm{~B} 8 \% \mathrm{D} 0 \% \mathrm{~B} 7 /$ sectorreview.aspx (дата обращения: 20.01.2021). - Загл. с экрана.

Балацкий, Е. В. Сравнительная надежность глобальных рейтингов университетов / Е. В. Балацкий, Н. А. Екимова // Журнал Новой экономической ассоциации. - 2011. - № 11. - С. 127-140.

Введение в «Цифровую» экономику / под общ. ред. А. В. Кешелава. - М. : ВНИИГеосистем, 2017. -28 c.

Евразийский экономический союз в цифрах: краткий статистический сборник. - М. : Евразийская экономическая комиссия, 2020. - 112 с.

Иванов, В. В. Инновационные территории как основа пространственной структуры национальной инновационной системы / В.В.Иванов // Регион: экономика и социология. 2015. - № 1. - С. 227-255.

Кастельс, М. Галактика Интернет: Размышления об Интернете, бизнесе и обществе / М. Кастельс ; под ред. В. Харитонова ; пер. с англ. А. Матвеева. - Екатеринбург : У-Фактория (при участии изд-ва Гуманит. ун-та), 2004. - 328 с.

Модели партнерств между компаниями стран Союза обсудили на форсайт-сессии по цифровым консорциумам в Ереване // Новости и события Евразийской экономической комиссии. - Электрон. текстовые дан. - Режим доступа: http:// www.eurasiancommission.org/ru/nae/news/ Pages/24_10_2018_5.aspx (дата обращения: 20.02.2021). - Загл. с экрана.

Паньшин, Б. Цифровая экономика: понятия и направления развития / Б. Паньшин // Наука и ииновации. - 2019. - № 3 (193). - С. 48-55.

Прогноз основных показателей экономического развития государств - членов ЕАЭС на 2020 2023 гг. (прогноз IV квартала 2020 года). Электрон. текстовые дан. - Режим доступа: http://www.eurasiancommission.org/ru/act/ integr_i_makroec/dep_makroec_pol/economy Prognoz/Pages/Sred_prog.aspx (дата обращения: 20.02.2021). - Загл. с экрана.

Программа «Цифровая экономика Российской Федерации» : утв. распоряжением Правительства РФ от 28 июля 2017 г. № 1632-р // Собрание законодательства РФ. - 2017. - № 32. - Ст. 5138.

Решение Высшего Евразийского экономического совета от 11.10.2017 № 12 «Об Основных направлениях реализации цифровой повестки Евразийс- кого экономического союза до 2025 года». Электрон. текстовые дан. - Режим доступа: http:/ /legalacts.ru/doc/reshenie-vysshego-evraziiskogoekonomicheskogo-soveta-ot-11102017-n-12/ (дата обращения: 20.02.2021). - Загл. с экрана.

Савчук, М. В. Подходы к внедрению ERP-систем на крупных предприятиях / M. В. Савчук, Р. В. Мещеряков // Бизнес-информатика. 2011. - №2 (16). - С. 63-67.

Стратегия развития информационного общества Российской Федерации на 2017-2030 годы : утв. указом Президента Российской Федерации от 09.05.2017 № 203 // Собрание законодательства РФ. - 2017. - № 20. - Ст. 2901.

Устюжанина, Е. В. Сетевая экономика как новая социально-экономическая система / Е. В. Устюжанина, И. П. Комарова // IV Российский экономический конгресс «РЭК-2020». Т. ХХ. Тематическая конференция «Цифровая экономика и сети» / сост.: В. Е. Дементьев, А. В. Леонидов. - М. : Новая экономическая ассоциация, 2020. - С. 82-84.

Цифровая повестка ЕАЭС 2016-2019-2025 : сборник. М. : Евразийская экономическая комиссия, 2019. - Электрон. текстовые дан. - Режим доступа: http://www.eurasiancommission.org/ru/ Documents/digital_agenda_eaeu.pdf(дата обращения: 20.01.2021). - Загл. с экрана.

Цифровая повестка Евразийского экономического союза до 2025 года: перспективы и рекомендации : обзор / Группа Всемирного банка, 2018. - Электрон. текстовые дан. - Режим доступа: http:/documents.vsemirnyjbank.org/ curated/ru/413921522436739705/The-EAEU2025 - digital - agenda-prospects - and recommendations-overview-report (дата обращения: 20.01.2021). - Загл. с экрана.

Юдина, Т. Н. Осмысление цифровой экономики / Т. Н. Юдина // Теоретическая экономика. 2016. - № 3. - С. 12-16.

Global Cybersecurity Index 2017. - Geneva, Switzerland : International Telecommunication Union, 2017. $-78 \mathrm{p}$.

Measuring the Information Society Report 2017. Vol. 1. - Geneva, Switzerland : International Telecommunication Union, 2017. - 170 p.

Measuring the Information Society Report 2017. Vol. 2. - Geneva, Switzerland : International Telecommunication Union, 2017. - 262 p.

The Global Information Technology Report 2016. Innovating in the Digital Economy. - Geneva : World Economic Forum, 2016. - 307 p.

The Network Readiness Index. Accelerating Digital Transformation in a post-COVID Global Economy. - Washington, DC : Portulans Institute, 2020. $-330 \mathrm{p}$. 
United Nations E-Government Surveys: 2020. Digital Government in the Decade of Action for Sustainable Development. - New York : United Nations, 2020. - 364 p.

World Development Indicators // World Bank, 2020. Electronic text data. - Mode of access: http:// wdi.worldbank.org/table/5.12 (date of access: 21.02.2021). - Title from screen.

\section{REFERENCES}

Analiz mirovogo opyta razvitiya promyshlennosti $i$ podkhodov $k$ tsifrovoj transformatsii promyshlennosti gosudarstv-chlenov Evrazijskogo ehkonomicheskogo soyuza: Informatsionno-analiticheskij otchet [Analysis of the World Experience in the Development of Industry and Approaches to the Digital Transformation of the Industry in the Eurasian Economic Union Member Countries. Information and Analytical Report]. Moscow, Evraziyskaya ekonomicheskaya komissiya, 2017. URL: http:// www.eurasiancommission.org/ru/act/prom_i agroprom/dep_prom/Pages/\%D0\%9C\%D0\% $\mathrm{BE} \% \mathrm{D} 0 \% \mathrm{BD} \% \mathrm{D} 0 \% \mathrm{~B} 8 \% \mathrm{D} 1 \% 82 \% \mathrm{D} 0 \% \mathrm{BE} \%$ D1\%80\%D0\%B8\%D0\%BD\%D0\%B3\%20\% D 0\%B $8 \% 20 \%$ D0\%B $0 \%$ D0\%BD\%D0\% B $0 \%$ D $0 \%$ B B \% D $0 \%$ B $8 \%$ D $0 \%$ B 7 / sectorreview.aspx (accessed 20 January 2021).

Balatskij E.V., Ekimova N.A. Sravnitel'naya nadezhnost' global'nykh rejtingov universitetov [The Comparative Reliability of the Global University Rankings]. Zhurnal Novoj ehkonomicheskoj assotsiatsii, 2011, no. 11, pp. 127-140.

Keshelav A.V., ed. Vvedenie v "Tsifrovuyu» ekonomiku [Introduction to the "Digital" Economy]. Moscow, VNIIGeosistem, 2017.28 p.

Evrazijskij jekonomicheskij sojuz v cifrah: kratkij statisticheskij sbornik [The Eurasian Economic Union in Numbers. Brief Statistical Compilation]. Moscow, Evraziyskaya ekonomicheskaya komissiya, 2020. 112 p.

Ivanov V.V. Innovatsionnye territorii kak osnova prostranstvennoj struktury natsional'noj innovatsionnoj sistemy [Innovative Territories As a Base for the Spatial Structure of the National Innovation System]. Region: ekonomika $i$ sotsiologiya [Region: Economics and Sociology], 2015, no. 1, pp. 227-255.

Kastel's M. Galaktika Internet: Razmyshleniya ob Internete, biznese $i$ obshhestve [The Internet Galaxy: Reflections on the Internet, Business and Society]. Ekaterinburg, U-Faktoriya (pri uchastii izd-va Gumanitarnogo universitetata), 2004. 328 p.
Modeli partnyorstv mezhdu kompaniyami stran Soyuza obsudili na forsajt-sessii po tsifrovym konsortsiumam v Erevane [Models of Partnerships Between Companies of the Union Countries were Discussed at the Foresight Session on Digital Consortium in Yerevan]. Novosti i sobytiya Evrazijskoj ehkonomicheskoj komissii [News and Events of the Eurasian Economic Commission]. URL: http://www. eurasiancommission.org/ru/nae/news/Pages/ 24_10_2018_5.aspx (accessed 20 February 2021).

Pan'shin B. Cifrovaja jekonomika: ponjatija i napravlenija razvitija [Digital Economy: Concepts and Directions of Development]. Nauka i innovatsii, 2019, no. 3 (193), pp. 48-55.

Prognoz osnovnyh pokazatelej jekonomicheskogo razvitija gosudarstv - chlenov EAJeS na 20202023 gg. (prognoz IV kvartala 2020 goda) [Forecast of the Main Indicators of Economic Development of the EAEU Member States for 2020-2023 (Forecast for the $4^{\text {th }}$ Quarter of 2020)]. URL: http://www.eurasiancommission.org/ru/ act/integr_i_makroec/dep_makroec_pol/ economyPrognoz/Pages/Sred_prog.aspx (accessed 20 February 2021).

Programma «Tsifrovaya ekonomika Rossijskoj Federatsii»: utv. rasporyazheniem Pravitel'stva RF ot 28 iyulya 2017 g. № 1632-r [The Program "Digital Economy of the Russian Federation". Approved by the Decree of the Government of the Russian Federation No. 1632-r Dated July 28, 2017]. Sobranie zakonodatel'stva RF [Collection of Legislation of the Russian Federation], 2017, no. 32, art. 5138.

Reshenie Vysshego Evrazijskogo ekonomicheskogo soveta ot 11.10.2017 № 12 «Ob Osnovnykh napravleniyakh realizatsii tsifrovoj povestki Evrazijskogo ehkonomicheskogo soyuza do 2025 goda» [Decision of the Supreme Eurasian Economic Council No. 12 Dated October 11, 2017 "On the Main Directions for Implementing the Digital Agenda of the Eurasian Economic Union Until 2025"]. URL: http://legalacts.ru/doc/ reshen i e-vys sh eg o-evrazi is ko goekonomicheskogo-soveta-ot-11102017-n-12 (accessed 20 February 2021).

Savchuk M.V., Meshheryakov R.V. Podkhody k vnedreniyu ERP-sistem na krupnykh predpriyatiyakh [Review of Approaches in Implementation of ERP Systems in Large Enterprises]. Biznes-informatika [Business Informatics], 2011, no. 2(16), pp. 63-67.

Strategiya razvitiya informatsionnogo obshhestva Rossijskoj Federatsii na 2017-2030 gody: utv. ukazom Prezidenta Rossijskoj Federatsii ot 09.05.2017 №2 03 [The Strategy for the 
Development of the Information Society in the Russian Federation for 2017-2030. Approved by the Decree of the President of the Russian Federation No. 203 Dated May9, 2017]. Sobranie zakonodatel'stva $R F$ [Collection of Legislation of the Russian Federation], 2017, no. 20, art. 2901.

Ustyuzhanina E.V., Komarova I.P. Setevaja jekonomika kak novaja social'no-jekonomicheskaja sistema [Network Economy As a New Socio-Economic System]. Dement'ev V.E., Leonidov A.V., eds. IV Rossijskij ehkonomicheskij kongress «REK2020». Tom XX. Tematicheskaya konferentsiya "Tsifrovaya ekonomika $i$ seti» [The $4^{\text {th }}$ Russian Economic Congress “REC-2020”. Vol. 20. Thematic Conference "Digital Economy and Networks"]. Moscow, Novaya ekonomicheskaya assotsiatsiya, 2020, pp. 82-84.

Cifrovaja povestka EAJeS 2016-2019-2025: sbornik [Digital Agenda of the EAEU 20162019-2025. Collection]. Moscow, Evraziyskaya ekonomicheskaya komissiya, 2019. URL: http:/ / www. eurasiancom mission.org/ru/ Documents/digital_agenda_eaeu.pdf (accessed 20 January 2021).

Tsifrovaya povestka Evrazijskogo ekonomicheskogo soyuza do 2025 goda: perspektivy $i$ rekomendatsii: obzor [The EAEU 2025 Digital Agenda: Prospects and Recommendations. Overview]. Gruppa Vsemirnogo Banka, 2018. URL: http://documents.vsemirnyjbank.org/
curated/ru/413921522436739705/The-EAEU2025 - digital-agend a-prospects - and recommendations-overview-report (accessed 20 January 2021).

Yudina T.N. Osmyslenie tsifrovoj ehkonomiki [Understanding the Digital Economy]. Teoreticheskaya ekonomika, 2016, no. 3, pp. 12-16.

Global Cybersecurity Index 2017. Geneva, International Telecommunication Union, 2017. $78 \mathrm{p}$.

Measuring the Information Society Report 2017. Geneva, International Telecommunication Union, 2017, vol. 1. 170 p.

Measuring the Information Society Report 2017. Geneva, International Telecommunication Union, 2017, vol. 2. 262 p.

The Global Information Technology Report 2016. Innovating in the Digital Economy. Geneva, World Economic Forum, 2016. 307 p.

The Network Readiness Index. Accelerating Digital Transformation in a Post-COVID Global Economy. Washington, DC, Portulans Institute, $2020.330 \mathrm{p}$.

United Nations E-Government Surveys: 2020. Digital Government in the Decade of Action for Sustainable Development. New York, United Nations, 2020. 364 p.

World Development Indicators. World Bank, 2020. URL: http://wdi.worldbank.org/table/5.12 (accessed 21 February 2021).

\section{Information About the Author}

Ekaterina A. Sidorova, Candidate of Sciences (Economics), Associate Professor, Department of Management, International Academy of Business and New Technologies, Sovetskaya St, 80, 150003 Yaroslavl, Russian Federation, ekaterina-sidorova1@yandex.ru, https://orcid.org/0000-0002-6953-9683

\section{Информация об авторе}

Екатерина Александровна Сидорова, кандидат экономических наук, доцент кафедры менеджмента, Международная академия бизнеса и новых технологий, ул. Советская, 80, 150003 г. Ярославль, Российская Федерация, ekaterina-sidorova1@yandex.ru, https:/orcid.org/0000-0002-6953-9683 